\title{
Sosialhjelpsmottakeres dødelighet: I hvilken grad kan overdødeligheten tilskrives deres sosiale status?
}

\author{
Sille Ohrem Naper ${ }^{1}$ og Espen Dahl ${ }^{2}$ \\ 1) Gruppe for inkluderende velferd, Avdeling for samfunnsfag, Høgskolen i Oslo \\ 2) Helse, omsorg, velferd, Høgskolen i Oslo
}

Korrespondanse: Sille Ohrem Naper, Høgskolen i Oslo, Avd. SAM, Postboks 4 St. Olavs plass, 0130 Oslo

Telefon: 22453624 Mobil: 97594299 Telefaks: 22453600 E-post: sille.ohremnaper@sam.hio.no

\begin{abstract}
SAMMENDRAG
I denne artikkelen undersøker vi dødelighet blant sosialhjelpsmottakere i Norge, som sammenlignes med dødeligheten i resten av befolkningen, og om en antatt overdødelighet kan forklares ved sosiale forhold som kjennetegner dem som har status som sosialhjelpsmottakerne, og som har betydning for dødelighetsnivå.

Data er hentet fra FD-trygd og omfatter hele den norske befolkningen i aldersgruppen 18-57 år i 1992. Vi analyserer dødeligheten fra 1994 til 2003. Sosialhjelpsmottakere er definert som personer som mottok sosialhjelp i 1993 ( $N=146$ 176), og det skilles mellom korttids- og langtidsmottakere ( $\geq 6$ måneder). Menn og kvinner behandles separat. En serie multiple Cox regresjonsmodeller er estimert for å belyse problemstillingene.

Den enkleste modellen, som kun inneholder sosialhjelp og alder, viser at dødeligheten til sosialhjelpsmottakere er langt høyere enn andres. Hasardratioene (HR) for mannlige kortidsmottakere av sosialhjelp sammenlignet med befolkningen er 3,5 $(95 \% \mathrm{KI}=3,34-3,62)$, for langtidsmottakere $4,8(4,64-5,01)$. For kvinner er HR henholdsvis $2,8(2,60-2,93)$ og 3,9 (3,66-4,15). Overdødeligheten blant sosialhjelpsmottakere reduseres ettersom forklaringsvariablene introduseres. I den fulle modellen, som inneholder alder, sivilstand, utdanning, inntekt og uførepensjon, er HR for kvinner redusert med 60 prosent for korttidsmottakere, og 50 prosent for langtidsmottakere, noe mindre for menn. HR er fortsatt høye i de justerte modellene, særlig for langtidsmottakere av sosialhjelp. De er nå for menn, korttid: $2,1(1,98-2,15)$ og langtid: $3,1(2,98-3,23)$, kvinner, korttid: 1,7 (1,61-1,82) og langtid: 2,5 (2,29-2,62).

I lys av tidligere forskning på feltet argumenter vi for at et livsløpsperspektiv er fruktbart for å forstå sosialhjelpsmottakeres overdødelighet. Samtidig peker vi på flere trekk ved posisjonen som sosialhjelpsmottaker som kan være helseskadelig.
\end{abstract}

\section{Napr SO, Dahl E. Mortality in recipients of social assistance in Norway: To which extent can excess mortality be ascribed to social status? Nor J Epidemiol 2007; 17 (1): 21-28.}

\section{ENGLISH SUMMARY}

In this article we analyse the mortality of the recipients of social assistance (SA) in Norway, asking to which degree it deviates from that of the general population, and to which extent the hypothesized excess mortality may be explained by socioeconomic factors that characterize the SA recipients.

The data are collected from administrative registries that cover the entire population. Our research population is restricted to those aged 18-57 years at baseline in 1992. Social assistance and income is measured in 1993, and the other covariates are measured at baseline. Mortality is measured during a period of ten years (1994-2003). Men and women are analysed separately. A series of Cox's regression models are estimated to examine the research questions, and hazard ratios (HR) are reported.

The mortality of SA recipients, only adjusted for age, is considerably higher than the mortality of the rest of the population. The age-adjusted hazard ratios (HR) for male short term SA recipients is $3.5(95 \% \mathrm{CI}=$ 3.34-3.62) and for long term recipients ( $\geq 6$ months) 4.8 (4.64-5.01). For women the HR are 2.8 (2.60-2.93) and 3.9 (3.66-4.15), respectively. Hence, the mortality of long term recipients is markedly higher than that of short term recipients. The excess mortality is then successively reduced as more covariates are introduced. Differences in marital status contributed most to this reduction. In the full model, controlling for age, marital status, education, income and disability pension, the HR for female recipients are reduced by 60 percent (short term) and 50 percent (long term), and for male recipients the HR are reduced by 57 percent (short term) and 45 percent (long term). Yet, despite these rather extensive controls, the mortality among SA recipients is still substantially higher than the mortality of the general population. The HR are now, for men, short term: 2.1 (1.98-2.15) and long term: 3.1 (2.98-3.23), female short term: 1.7 (1.61-1.82), and long term: 2.5 (2.29-2.62). For men, the excess mortality is even higher than what is found for disability pensioners.

In view of previous research in this field, we argue that a life course perspective offers a promising perspective to explain the high mortality rate of SA recipients. Selected features of the status as a SA recipient that are known to have a detrimental effect on health are also addressed. 


\section{INNLEDNING}

Denne artikkelen tar for seg dødelighet blant sosialhjelpsmottakere og har både en deskriptiv og en forklarende ambisjon. Vi spør for det første hvordan dødeligheten blant sosialhjelpsmottakere avviker fra dødeligheten i resten av befolkningen. Hypotesen er at de har høyere dødelighet. For det andre spør vi i hvilken grad den forventede overdødeligheten kan tilskrives deres sosiale status. Med dette mener vi her inntekt, utdanning, sivilstand og uførepensjon.

Norsk forskning om sosiale ulikheter i helse og dødelighet har i hovedsak rettet søkelyset mot det forhold at ulikhet $\mathrm{i}$ helse finnes mellom alle lag i samfunnet, også blant de bedre stilte (1). I den siste tiden har det imidlertid kommet flere studier som viser spesielt høy dødelighet blant marginaliserte grupper (2). I tillegg til at det er en generell sammenheng mellom inntekt og dødelighet (3), viser det seg at denne sammenhengen ikke er lineær: de med lavest inntekt har markert høyere dødelighet enn de øvrige inntektsgruppene $(4,5)$. Både barnevernsbarn og domfelte har høy dødelighet $(6,7)$, og dette er grupper med stor grad av overlapp med sosialhjelpsmottakere (7-10). Det er ikke tidligere gjort studier av sosialhjelpsmottakeres dødelighet i Norge, men en rekke levekårsundersøkelser som er gjennomført blant sosialhjelpsmottakere de siste 15 årene viser at det er langt større innslag av helseproblemer i denne gruppen enn i befolkningen ellers, og særlig er det en stor andel med psykiske lidelser (8,9,11-13). Svenske studier har påvist opp til fire ganger så høy risiko for å dø blant sosialhjelpsmottakere sammenlignet med andre menn og kvinner, varierende med kjønn og alder $(14,15)$. Basert på dette forventer vi høy dødelighet blant sosialhjelpsmottakere også i Norge.

Sosialhjelp er velferdsstatens nederste økonomiske sikkerhetsnett og skal sikre at alle som ikke kan sørge for seg selv har tilstrekkelige midler til livsopphold, forutsatt at alle andre muligheter først er utnyttet fullt ut. Sosialhjelp er ment å være kortvarig økonomisk hjelp i et knipetak. Blant annet av denne grunn holdes kommunale satser og statlige retningslinjer på et lavt nivå: Det skal lønne seg å jobbe. De aller fleste har også korte episoder av sosialhjelpsbruk. Likevel er det et ikke ubetydelig mindretall som mottar sosialhjelp kontinuerlig over lang tid, og enda flere som går ut og inn av sosialhjelpen i løpet av en lengre periode (16). På begynnelsen av nittitallet, som er utgangspunktet for denne undersøkelsen, hadde det vært en sterk økning i antall sosialhjelpsmottakere til cirka 160000 , eller 4 prosent av befolkningen (17). Toppen ble nådd $i$ 1994, mens i de siste årene har det ligget på rundt 130000 mottakere i året (3 prosent av befolkningen).

Lav inntekt er et sentralt kjennetegn ved sosialhjelpsmottakere. I 2003 tilhørte 43 prosent av sosialhjelpsmottakere lavinntektsgruppen (18), selv om ikke alle sosialhjelpsmottakere er fattige, og ikke alle som er inntektsfattige er sosialhjelpsmottakere (19). Den lave inntekten i gruppen kan være en indikasjon på helserelatert seleksjon ut av arbeidslivet. Sosialhjelpsmottakere har svak yrkestilknytning sammenlignet med den norske befolkningen $\mathrm{i}$ arbeidsfør alder for øvrig $(8,9)$, og helseproblemer kan være en av flere grunner til at de faller ut av arbeidslivet $(12,20)$. Men inntekt kan også representere en reell kausalforbindelse. Lav inntekt kan virke helsenedbrytende hovedsakelig som følge av to ulike mekanismer: enten via materielle mangler eller via psykososiale belastninger ved å være plassert nederst i inntektshierarkiet (21). Flere undersøkelser har vist at en del sosialhjelpsmottakere har økonomiske problemer som skaper materiell knapphet med betydning for helsen $(8,12,18)$. Dette tyder på at en del av den dårlige helsen blant sosialhjelpsmottakere skyldes absolutt materiell deprivasjon, men moderne fattigdom kan i langt større grad karakteriseres som relativ deprivasjon, det vil si å ikke ha ressurser til å anskaffe seg det folk flest har, og til å delta i samfunnet på lik linje med andre, noe som kan ha betydning for helse, velvære og dødelighet $(22,23)$.

Dødelighet varierer også med utdanningsnivå (24). Blant sosialhjelpsmottakere er det en overvekt av personer med lav utdanning og få som har oppnådd høyere utdanning (25). Noe av overdødeligheten blant sosialhjelpsmottakere kan derfor sannsynligvis tilskrives at det er flere lavt utdannede i denne gruppen. Lav utdanning medfører ikke økt dødelighet i seg selv, men kan blant annet være utrykk for sosial posisjon. I en studie fra Nederland fant man at materielle faktorer kunne forklare mest av sammenhengen mellom utdanningsforskjeller i dødelighet (26).

Personer som lever alene har høyere dødelighet enn personer som lever i samliv (27-30). Videre er sammenhengen mellom dårlig helse og lav inntekt og utdanning sterkere for enslige personer enn for personer som lever i husholdninger med to eller flere (31). Blant sosialhjelpsmottakere er det en liten andel som er gift og en stor andel som er skilt, sammenlignet med resten av befolkningen $(8,25)$. Andelen skilte og separerte vokste kraftig på 1980-tallet, og det ble hevdet at dette var den viktigste enkeltfaktoren for å forklare veksten i antall sosialhjelpsmottakere (32).

Flere internasjonale studier har vist at det er markert høyere dødelighet blant uførepensjonister enn blant andre (33). Det samme gjelder i Norge (34). Sosialhjelpsmottakere har en del likhetspunkter med, men skiller seg også vesentlig fra, uførepensjonister. Mens uførepensjonister per definisjon er utenfor arbeidet som følge av helsesvikt som reduserer arbeidsevnen, antar man ofte at sosialhjelpsmottakere har "sosiale problemer", og er i stand til å jobbe. Begge gruppene har lav inntekt sammenlignet med den øvrige befolkningen, men dette gjelder i større grad for sosialhjelpsmottakerne enn for uførepensjonister (35). I tillegg kan sosialhjelpsmottakerne oppleve stigmatisering og tap av selvrespekt (36), og ytelsen er i tillegg til å være lav også uforutsigbar, noe som kan medføre helseskadelig kronisk stress (12). Det er også en del sosialhjelps- 
mottakere som har fått tilkjent uførepensjon, men som har behov for sosialhjelp som tilleggsytelse. Denne type sambruk utgjør en liten andel av alle uførepensjonister, men en ikke ubetydelig andel av sosialhjelpsmottakerne (25).

Til tross for at gruppen av sosialhjelpsmottakere som helhet er problembelastet og ressurssvak, er det viktig å være klar over at sosialhjelpsmottakere er en heterogen gruppe, blant annet fordi de utgjør en restkategori som ikke fanges opp av andre ytelser i velferdsstaten. Noe av denne heterogeniteten fanges opp av skillet mellom langtids- og korttidsmottakere av sosialhjelp som vi vil bruke i denne analysen. Tidligere forskning har vist at det særlig er langtidsmottakere som rapporterer om sammensatte problemer og mangel på sosiale ressurser $(8,25,37)$.

\section{DATA OG METODE}

Datamaterialet er hentet fra administrative registerdata (FD-trygd (38)) og inkluderer opplysninger om alder, kjønn, sivilstand, utdanning, inntekt, uførepensjon og sosialhjelp og dødsfall. Vårt utvalg består av alle mellom 18 og 57 år som var bosatt i Norge per 31.12. 1992, totalt 2354895 personer. Derav var det 61319 personer (2,6 prosent) som ikke kunne følges i hele observasjonsperioden og som derfor er ekskludert fra studien. I utvalget var det 146176 personer som mottok sosialhjelp for en kortere eller lengre periode i løpet av 1993. Data om dødsfall i tiårsperioden fra 1994 til 2003 er koblet til. Blant sosialhjelpsmottakerne døde 7777 i løpet av den ti år lange oppfølgingsperioden, mot 50789 i den øvrige befolkningen (tabell 1).

En korttidsmottaker av sosialhjelp er her definert som en person som mottok økonomisk sosialhjelp mellom en og fem måneder i 1993. En langtidsmottaker av sosialhjelp mottok sosialhjelp i seks måneder eller mer i 1993. Disponibel ekvivalert familieinntekt tar utgangspunkt i summen av alle familiemedlemmenes inntekter minus skatt og er ekvivalert etter antall familiemedlemmer. Den er delt inn i fem deler. Personer med negativ eller null inntekt er ekskludert fra analysen. Inntekt er som sosialhjelp målt i 1993, de øvrige kovariatene i 1992.

Sivilstand er angitt med kategoriene gift, ugift og tidligere gift. Utdanningsnivå er høyeste oppnådde utdanning registrert i 1992, delt inn i fire kategorier: Universitet/høgskole, videregående skole nivå II (1112 år), videregående nivå I (10 år) og grunnskole. Uførepensjon er offentlig uførepensjon fra folketrygden. Fordi vi var interessert $\mathrm{i}$ å sammenligne det relative bidraget til utdanningsnivå og inntekt for å forklare den høye dødeligheten til sosialhjelpsmottakere, ble disse variablene lagt til i analysen i hver sin modell. Alder er målt kontinuerlig. Siden risikoen for død varierer sterkt med alder, og vi vet at sosialhjelpsmottakerne som gruppe er betydelig yngre enn befolkningen, er det nødvendig å kontrollere for alder $\mathrm{i}$ alle analysene. Fordelingen på de ulike variablene vises i tabell 1, sammen med antall dødsfall i hver kategori.
Tabell 1. Antall personer fordelt på de uavhengige variablene og antall dødsfall for menn og kvinner.

\begin{tabular}{|c|c|c|c|c|}
\hline & \multicolumn{2}{|c|}{ Antall personer } & \multicolumn{2}{|c|}{ Antall dødsfall } \\
\hline & Menn & Kvinner & Menn & Kvinner \\
\hline Totalt & 1203543 & 1151352 & 37315 & 21280 \\
\hline Antall ukjent utfall & 33695 & 27624 & & \\
\hline \multicolumn{5}{|l|}{ Sosialhjelp } \\
\hline Ikke mott. & 1122665 & 1085359 & 31837 & 19176 \\
\hline Korttid & 46083 & 41055 & 2751 & 1111 \\
\hline Langtid & 34418 & 24620 & 2727 & 993 \\
\hline Ukjent & 377 & 318 & 0 & 0 \\
\hline Alder - gj.snitt & 35,9 & 36,0 & & \\
\hline \multicolumn{5}{|l|}{ Sivilstand } \\
\hline Gift & 571895 & 620045 & 17529 & 12356 \\
\hline Aldri gift & 520962 & 389087 & 12112 & 3790 \\
\hline Tidl. gift & 110671 & 142198 & 7673 & 5133 \\
\hline Ukjent & 15 & 22 & 1 & 1 \\
\hline \multicolumn{5}{|l|}{ Utdanning } \\
\hline Høgsk./ Uni. & 258675 & 248338 & 5006 & 2754 \\
\hline Vid.g. høy & 441070 & 304875 & 9184 & 2655 \\
\hline Vid.g. lav & 247651 & 342892 & 9129 & 7338 \\
\hline Gr.skole & 253440 & 252971 & 13958 & 8512 \\
\hline Ukjent & 2707 & 2276 & 38 & 21 \\
\hline \multicolumn{5}{|l|}{ Inntekt } \\
\hline Нøу & 270200 & 200027 & 7810 & 4401 \\
\hline 4 & 254832 & 233786 & 7304 & 4163 \\
\hline 3 & 243480 & 249507 & 7198 & 4402 \\
\hline 2 & 213679 & 228867 & 7353 & 4321 \\
\hline Lav & 198277 & 224067 & 7180 & 3786 \\
\hline Ukjent & 23075 & 15098 & 470 & 207 \\
\hline \multicolumn{5}{|l|}{ Uførep. } \\
\hline Nei & 1155676 & 1082677 & 29459 & 15449 \\
\hline $\mathrm{Ja}$ & 47867 & 68675 & 7856 & 5831 \\
\hline Ukjent & 0 & 0 & 0 & 0 \\
\hline
\end{tabular}

I de multivariate analysene av tidspunkt for død er det benyttet overlevelsesanalyseteknikken Cox' "proportional hazard" modell ved hjelp av statistikkprogrammet STATA (39). Hasardratioene, som uttrykker forholdet mellom hasardratene for de to gruppene som sammenlignes, er rapportert. Vi anvender en trinnvis analytisk tilnærming og beregner de prosentvise endringene $i$ hasardratioene til langtids- og korttidsmottakere av sosialhjelp sammenlignet med resten av befolkningen etter som vi legger til nye kovariater.

\section{Resultater}

Kun kontrollert for alder var hasardratioen for mannlige korttidsmottakere av sosialhjelp 3,5 og for langtidsmottakere 4,8 (tabell 2). Sammenligningskategorien var menn som ikke hadde mottatt sosialhjelp i 1993. For kvinner var hasardratioene 2,8 for korttidsmottakere og 3,9 for langtidsmottakere (tabell 3). Forskjellene i dødelighet er altså noe mindre for kvinner enn menn. I de neste modellene undersøker vi hvor mye av denne overdødeligheten som kan tilskrives kovariatene.

Hasardratioen for menn reduseres til 2,8 for korttidsmottakere og 3,8 for langtidsmottakere, og for 
Tabell 2. Relative dødelighetsrater (hasardratioer) med 95 prosent konfidensintervall (95\% KI) for menn.

\begin{tabular}{|c|c|c|c|c|c|c|c|c|c|c|c|c|}
\hline & \multirow{2}{*}{\multicolumn{2}{|c|}{$\begin{array}{l}\text { Modell } 1 \\
(95 \% \mathrm{KI})\end{array}$}} & \multicolumn{2}{|r|}{ Modell 2} & \multicolumn{2}{|r|}{ Modell 3} & \multicolumn{2}{|r|}{ Modell 4} & \multicolumn{2}{|r|}{ Modell 5} & \multicolumn{2}{|r|}{ Modell 6} \\
\hline & & & HR & $(95 \% \mathrm{KI})$ & HR & $(95 \% \mathrm{KI})$ & HR & $(95 \% \mathrm{KI})$ & HR & $(95 \% \mathrm{KI})$ & HR & $(95 \% \mathrm{KI})$ \\
\hline \multicolumn{13}{|l|}{ Sosialhjelp } \\
\hline Ikke mottatt & 1 & & 1 & & 1 & & 1 & & 1 & & 1 & \\
\hline Korttid & 3,48 & $(3,34-3,62)$ & 2,76 & $(2,65-2,87)$ & 2,46 & $(2,36-2,56)$ & 2,39 & $(2,29-2,49)$ & 2,25 & $(2,16-2,35)$ & 2,06 & $(1,98-2,15)$ \\
\hline Langtid & 4,82 & $(4,64-5,01)$ & 3,76 & $(3,62-3,91)$ & 3,27 & $(3,14-3,40)$ & 3,22 & $(2,09-3,36)$ & 2,98 & $(2,86-3,11)$ & 3,10 & $(2,98-3,23)$ \\
\hline Alder & 1,09 & $(1,09-1,09)$ & 1,11 & $(1,10-1,11)$ & 1,10 & $(1,10-1,10)$ & 1,11 & $(1,11-1,11)$ & 1,10 & $(1,10-1,10)$ & 1,09 & $(1,09-1,09)$ \\
\hline \multicolumn{13}{|l|}{ Sivilstand } \\
\hline Gift & & & 1 & & 1 & & 1 & & 1 & & 1 & \\
\hline Aldri gift & & & 2,40 & $(2,34-2,47)$ & 2,24 & $(2,18-2,30)$ & 2,44 & $(2,37-2,50)$ & 2,27 & $(2,21-2,33)$ & 1,90 & $(1,85-1,95)$ \\
\hline Tidl. gift & & & 1,89 & $(1,84-1,95)$ & 1,83 & $(1,78-1,88)$ & 1,95 & $(1,89-2,00)$ & 1,87 & $(1,82-1,92)$ & 1,70 & $(1,65-1,75)$ \\
\hline \multicolumn{13}{|l|}{ Utdanning } \\
\hline Høgsk./ Univ. & & & & & 1 & & & & 1 & & 1 & \\
\hline Vid.g. II & & & & & 1,36 & $(1,31-1,40)$ & & & 1,31 & $(1,26-1,35)$ & 1,28 & $(1,23-1,32)$ \\
\hline Vid.g. I & & & & & 1,72 & $(1,66-1,78)$ & & & 1,63 & $(1,57-1,69)$ & 1,55 & $(1,49-1,61)$ \\
\hline Gr.skole & & & & & 2,02 & $(1,95-2,08)$ & & & 1,89 & $(1,82-1,95)$ & 1,69 & $(1,63-1,75)$ \\
\hline \multicolumn{13}{|l|}{ Inntekt } \\
\hline Нøу & & & & & & & 1 & & 1 & & 1 & \\
\hline 4 & & & & & & & 1,21 & $(1,17-1,25)$ & 1,12 & $(1,08-1,16)$ & 1,08 & $(1,04-1,12)$ \\
\hline 3 & & & & & & & 1,33 & $(1,29-1,38)$ & 1,19 & $(1,15-1,23)$ & 1,08 & $(1,04-1,12)$ \\
\hline 2 & & & & & & & 1,52 & $(1,47-1,57)$ & 1,33 & $(1,28-1,37)$ & 1,09 & $(1,05-1,13)$ \\
\hline Lav & & & & & & & 1,55 & $(1,50-1,60)$ & 1,34 & $(1,29-1,38)$ & 1,14 & $(1,10-1,18)$ \\
\hline \multicolumn{13}{|l|}{ Uførepensjon } \\
\hline Nei & & & & & & & & & & & 1 & \\
\hline $\mathrm{Ja}$ & & & & & & & & & & & 2,53 & $(2,46-2,60)$ \\
\hline \multicolumn{13}{|c|}{$\underline{\text { Prosentvise endringer i } \mathrm{HR}^{1}}$} \\
\hline Modeller & Total & $($ Mod $1 \rightarrow$ Mod 6) & Moc & d. $1 \rightarrow$ Mod. 2 & Mo & d. $2 \rightarrow$ Mod. 3 & Moc & d. $2 \rightarrow$ Mod. 4 & Moc & d. $2 \rightarrow$ Mod. 5 & Mo & 1. $5 \rightarrow$ Mod. 6 \\
\hline Kort tid & & $57 \%$ & & $29 \%$ & & $17 \%$ & & $21 \%$ & & $29 \%$ & & $15 \%$ \\
\hline Lang tid & & $45 \%$ & & $28 \%$ & & $18 \%$ & & $20 \%$ & & $28 \%$ & & $-6 \%$ \\
\hline
\end{tabular}

${ }^{1}\left(\mathrm{HR}_{\text {mod.x }}-\mathrm{HR}_{\text {mod.y }}\right) /\left(\mathrm{HR}_{\text {mod.x }}-1\right)$

kvinner til henholdsvis 2,3 og 3,2 når vi inkluderer sivilstand $\mathrm{i}$ analysen (modell 2). Dette innebærer en reduksjon i hasardratioene på rundt 23 prosent for kvinner og rundt 28 prosent for menn.

Ved å inkludere utdanning eller inntekt reduseres hasardratioene med i underkant av 20 prosent (modell 3 og 4). Inntekt ser ut til å ha noe større betydning enn utdanning for menn, mens det er omvendt for kvinner, men forskjellene er minimale. I modell 5 kontrollerer vi for inntekt og utdanning samlet. For menn er hasardratioene da 2,3 for korttidsmottakere og 3,0 for langtidsmottakere. For kvinner er hasardratioene nå på 2,0 for korttidsmottakere og 2,6 for langtidsmottakere. Sammenlignet med hasardratioen i modell 2 har vi oppnådd en reduksjon i hasardratioen på mellom $27 \mathrm{og}$ 29 prosent ved å kontrollere for inntekt og utdanning. Det vil si at den samlede reduksjonen ved å kontrollere for utdanning og inntekt er noe mindre enn summen av reduksjonene som oppnås når kovariatene legges inn hver for seg, og de to variablene er derfor delvis uttrykk for den samme underliggende dimensjonen. Selv etter at vi har kontrollert for disse kovariatene er hasardratioene for sosialhjelpsmottakere betydelig større enn for de som ikke mottok sosialhjelp, og hasardratioene er fremdeles større enn forskjellene som følger av inntekt og utdanningsnivå.

Modell 6 viser at hasardratioen reduseres fra 2,3 til 2,1 for mannlige korttidsmottakere av sosialhjelp, mens hasardratioen er høyere for langtidsmottakere av sosialhjelp når vi i tillegg kontrollerer for uførepensjon. Reduksjonen ved å kontrollere for uførepensjon er større for kvinner: hasardratioen reduseres fra 2,0 til 1,7 for korttidsmottakere av sosialhjelp, og fra 2,6 til 2,5 for langtidsmottakere av sosialhjelp. Mannlige langtidsmottakere av sosialhjelp har høyere dødelighet enn uførepensjonistene, mens for kvinner er den omtrent like høy. De som mottar både uførepensjon og sosialhjelp har høyere dødelighet enn alle andre. For mannlige uførepensjonister som også mottok supplerende sosialhjelp i minst seks måneder i 1993 er hasardratioen $(3,1 * 2,5)$ på 7,8 sammenlignet med menn som ikke mottok disse ytelsene.

Totalt kan 57 prosent (korttid) og 45 prosent (langtid) av overdødeligheten til mannlige sosialhjelpsmottakere tilskrives ulikheter i utdanning, inntekt, sivilstand og uførepensjonering. For kvinner reduseres overdødeligheten blant korttidsmottakere til sammen med 60 prosent og blant langtidsmottakere 50 prosent av disse forholdene.

\section{DISKUSJON}

Det er en begrensning i studien at vi kun har opplysninger om sosialhjelp for ett år, noe som kan føre til feilklassifiseringer i inndelingen i korttids- og langtidsmottakere. Mange personer kan ha mottatt sosialhjelp i en tidligere eller senere periode, og sosialhjelpsepisoden vi har observert kan strekke seg over lengre tid 
Tabell 3. Relative dødelighetsrater (hasardratioer) med 95 prosent konfidensintervall ( $95 \% \mathrm{KI}$ ) for kvinner.

\begin{tabular}{|c|c|c|c|c|c|c|c|c|c|c|c|c|}
\hline & \multirow[b]{2}{*}{ HR } & \multirow{2}{*}{$\begin{array}{l}\text { Modell } 1 \\
(95 \% \mathrm{KI})\end{array}$} & \multicolumn{2}{|r|}{ Modell 2} & \multirow[b]{2}{*}{ HR } & \multirow{2}{*}{$\begin{array}{l}\text { Modell } 3 \\
(95 \% \mathrm{KI})\end{array}$} & \multirow[b]{2}{*}{ HR } & \multicolumn{2}{|l|}{ Modell 4} & \multirow{2}{*}{$\begin{array}{r}\text { Modell } 5 \\
(95 \% \text { KI })\end{array}$} & \multicolumn{2}{|c|}{ Modell 6} \\
\hline & & & HR & $(95 \% \mathrm{KI})$ & & & & $(95 \% \mathrm{KI})$ & HR & & HR & $(95 \% \mathrm{KI})$ \\
\hline \multicolumn{13}{|l|}{ Sosialhjelp } \\
\hline Ikke mottatt & 1 & & 1 & & 1 & & 1 & & 1 & & 1 & \\
\hline Korttid & 2,76 & $(2,60-2,93)$ & 2,34 & $(2,20-2,49)$ & 2,08 & $(1,95-2,21)$ & 2,11 & $(1,98-2,25)$ & 1,97 & $(1,85-2,10)$ & 1,71 & $(1,61-1,82)$ \\
\hline Langtid & 3,90 & $(3,66-4,15)$ & 3,22 & $(3,02-3,43)$ & 2,78 & $(2,61-2,97)$ & 2,87 & $(2,68-3,06)$ & 2,62 & $(2,45-2,80)$ & 2,45 & $(2,29-2,62)$ \\
\hline Alder & 1,10 & $(1,10-1,10)$ & 1,11 & $(1,10-1,11)$ & 1,10 & $(1,10-1,10)$ & 1,11 & $(1,11-1,11)$ & 1,10 & $(1,10-1,10)$ & 1,09 & $(1,09-1,09)$ \\
\hline \multicolumn{13}{|l|}{ Sivilstand } \\
\hline Gift & & & 1 & & 1 & & 1 & & 1 & & 1 & \\
\hline Aldri gift & & & 1,77 & $(1,70-1,85)$ & 1,82 & $(1,75-1,90)$ & 1,76 & $(1,69-1,84)$ & 1,81 & $(1,73-1,88)$ & 1,57 & $(1,51-1,64)$ \\
\hline Tidl. gift & & & 1,38 & $(1,33-1,42)$ & 1,37 & $(1,32-1,42)$ & 1,33 & $(1,28-1,38)$ & 1,34 & $(1,30-1,39)$ & 1,25 & $(1,20-1,29)$ \\
\hline \multicolumn{13}{|l|}{ Utdanning } \\
\hline Høgsk./ Univ. & & & & & 1 & & & & 1 & & 1 & \\
\hline Vid.g. II & & & & & 1,19 & $(1,13-1,26)$ & & & 1,17 & $(1,11-1,23)$ & 1,13 & $(1,07-1,19)$ \\
\hline Vid.g. I & & & & & 1,44 & $(1,38-1,51)$ & & & 1,39 & $(1,33-1,45)$ & 1,32 & $(1,26-1,38)$ \\
\hline Gr.skole & & & & & 1,89 & $(1,81-1,98)$ & & & 1,79 & $(1,71-1,87)$ & 1,56 & $(1,49-1,63)$ \\
\hline \multicolumn{13}{|l|}{ Inntekt } \\
\hline Нøу & & & & & & & 1 & & 1 & & 1 & \\
\hline 4 & & & & & & & 1,10 & $(1,05-1,15)$ & 1,03 & $(0,99-1,08)$ & 0,99 & $(0,95-1,04)$ \\
\hline 3 & & & & & & & 1,19 & $(1,14-1,24)$ & 1,08 & $(1,03-1,13)$ & 0,99 & $(0,95-1,04)$ \\
\hline 2 & & & & & & & 1,30 & $(1,25-1,36)$ & 1,15 & $(1,10-1,20)$ & 1,00 & $(0,95-1,04)$ \\
\hline Lav & & & & & & & 1,49 & $(1,42-1,56)$ & 1,27 & $(1,22-1,34)$ & 1,11 & $(1,06-1,16)$ \\
\hline \multicolumn{13}{|l|}{ Uførepensjon } \\
\hline Nei & & & & & & & & & & & 1 & \\
\hline $\mathrm{Ja}$ & & & & & & & & & & & 2,40 & $(2,32-2,48)$ \\
\hline \multicolumn{3}{|c|}{ Prosentvise endringer i HR } & \multirow{2}{*}{\multicolumn{2}{|c|}{ Mod. $1 \rightarrow$ Mod. 2}} & \multirow{2}{*}{\multicolumn{2}{|c|}{ Mod. $2 \rightarrow$ Mod. 3}} & \multirow{2}{*}{\multicolumn{2}{|c|}{ Mod. $2 \rightarrow$ Mod. 4}} & \multirow{2}{*}{\multicolumn{2}{|c|}{ Mod. $2 \rightarrow$ Mod. 5}} & \multirow{2}{*}{\multicolumn{2}{|c|}{ Mod. $5 \rightarrow$ Mod. 6}} \\
\hline Modeller & Total & $(\operatorname{Mod} 1 \rightarrow \operatorname{Mod} 6)$ & & & & & & & & & & \\
\hline Kort tid & & $60 \%$ & & $24 \%$ & & $19 \%$ & & $17 \%$ & & $28 \%$ & & $27 \%$ \\
\hline Lang tid & & $50 \%$ & & $23 \%$ & & $20 \%$ & & $16 \%$ & & $27 \%$ & & $10 \%$ \\
\hline
\end{tabular}

enn det vi har fanget opp. Til tross for disse mulighetene for feilklassifisering viser det seg at varighet som sosialhjelpsmottaker over en periode på ett år er en sentral og robust markør for sosiale og helsemessige problemer. Dette er i tråd med annen forskning på området $(25,37)$.

Dødeligheten blant sosialhjelpsmottakere i perioden 1994-2003 var betydelig høyere enn blant dem som ikke mottok sosialhjelp. Dette var i tråd med hva vi kunne forvente, basert på at andre studier har vist langt større innslag av somatiske og psykiske helseproblemer i gruppen, og at sosialhjelpsmottakere som gruppe har lav inntekt, lite utdanning, overhyppighet av enslige og et visst innslag av uførepensjonister med behov for sosialhjelp som subsidiær ytelse, alle kjennetegn som vi vet fører til høyere prematur dødelighet. Disse sosiale forholdene reduserte den observerte overdødeligheten med over halvparten, mer for korttidsmottakere enn for langtidsmottakere. Det som er interessant $\mathrm{i}$ denne sammenheng er at det likevel ikke er disse forholdene alene som forklarer overdødeligheten, langt ifra. Selv etter kontroll for disse forholdene har mannlige korttidsmottakere av sosialhjelp dobbelt så høy dødelighet og langtidsmottakere tre ganger så høy dødelighet som menn som ikke mottok sosialhjelp, og for kvinner er forskjellene bare noe mindre, med hasardratioer på henholdsvis 1,7 og 2,5. Inntekt og utdanning reduserer hasardratioene med omtrent like mye. Utdanning og inntekt er ikke nødvendigvis uttrykk for den samme underliggende sosiale posisjonen, selv om de er korrelert. Dette er i tråd med andre studier som har vist at de har separate effekter på helse og for tidlig død (40).

Sivilstand - det faktum at det er flere enslige blant sosialhjelpsmottakerne enn i den øvrige befolkningen - bidro til å forklare minst like mye av reduksjonen $\mathrm{i}$ sammenhengen mellom sosialhjelp og dødelighet. Som nevnt $\mathrm{i}$ innledningen har tidligere studier vist at særlig enslige med lav inntekt og utdanning har høy dødelighet. Sammenhengen mellom helse og sivilstand kan forklares både med seleksjon av personer med dårlig helse til en status som enslig og med at ekteskapet har en beskyttende effekt på helsen av både psykososial og økonomisk karakter (41). Begge typene av forklaringer kan tenkes å være spesielt relevante i dette tilfellet. Personer som både har dårlig helse og mottar sosialhjelp er trolig lite attraktive ekteskapspartnere. Enslige er overrepresentert blant dem med lav inntekt (42), og for personer med lav inntekt er fraværet av stordriftsfordelene man får med å være gift spesielt merkbart.

Et svært interessant funn er det at langtidsmottakere av sosialhjelp har høyere dødelighet enn uførepensjonister. Dette er i tråd med funn fra van der Wel m.fl. som viste at det var flere sosialhjelpsmottakere enn uførepensjonister med dårlig selvrapportert helse (8), et mål som sterkt predikerer senere dødelighet (43). Den som ikke er i stand til å arbeide, helt eller delvis, på grunn av helsemessige problemer, har i utgangspunktet rett til sykdomsrelaterte trygdeytelser, midlertidige eller permanente. For noen som mangler slike rettigheter, eller som ikke mottar tilstrekkelige ytelser, kan sosialhjelp bli en løsning, på kort eller lang sikt. Det foregår med andre ord en seleksjon av personer som er syke inn i sosialhjelpsordningen, og 
dette kan forklare en del av den påviste sammenhengen mellom sosialhjelpsmottak og helse. Vi vet imidlertid foreløpig lite om den relative betydningen av dette, og i hvor stor grad man faktisk blir syk(ere) og dør av å leve som sosialhjelpsmottaker over tid. Man skal heller ikke overdrive forskjellene mellom uførepensjonister og sosialhjelpsmottakere. De fleste blir uførepensjonert som følge av ikke-dødelige diagnoser, og en del av den høye dødeligheten kan tilskrives mye av de samme risikofaktorene som for sosialhjelpsmottakere (33).

Til tross for at mye av overdødeligheten blant sosialhjelpsmottakere ble redusert av våre statistiske modeller, gjenstår det en betydelig sammenheng mellom sosialhjelpsmottak og dødelighet, spesielt for langtidsmottakere. Vi kan bare spekulere i hva disse andre forholdene kan være. På grunnlag av andre undersøkelser av sosialhjelpsmottakere vil vi peke på to forhold, som antakelig henger sammen: levekår under oppveksten og andre forhold i samtiden som ikke er målt. Når man ikke kan kontrollere for dette, vil sammenhengen mellom sosialhjelpsbruk og dødelighet bli overestimert (14).

Oppvekstforhold har betydning for helse, sykelighet og dødelighet $\mathrm{i}$ voksen alder $(44,45)$. Tidligere forskning på sosialhjelpsmottakeres oppvekstvilkår har vist at store andeler opplevde betydelige problemer under oppveksten, som mobbing, rusmisbruk i familien, avbrudd i skolegangen, og fattigdom $(8,9)$. Problematiske oppvekstforhold kan her fungere som en bakenforliggende variabel, da det kan gi forhøyet risiko for sosialhjelpsbruk som voksen i tillegg til dårlig helse og tidlig død $(46,47)$. Det er således en mulighet for at det er slike vanskelige oppvekstvilkår som kan forklare en del av overdødeligheten blant sosialhjelpsmottakerne. Likevel vil vi være forsiktige med å hevde at en problematisk oppvekst betyr alt. Det er høy forekomst av rusmisbruk i gruppen $(8,9,48)$. Åtti prosent av sosialhjelpsmottakerne i 1990 røykte, dobbelt så mange som i den øvrige befolkningen på den tiden (49). Det kan være at denne typen helseskadelig atferd også spiller en betydelig rolle. Vi kan imidlertid ikke isolere denne typen helseatferd fra sosialhjelpsmottakernes oppveksterfaringer og øvrige livserfaringer. Spesielt slående i tidligere undersøkelser av sosialhjelpsmottakeres helse er den høye andelen med psykiske lidelser. Blant langtidsmottakerne er det funnet at så mange som 60 prosent sliter med angst og/eller depresjon (8). Depresjon har betydning for dødelighet også kontrollert for helserelatert atferd, annen sykdom og sosioøkonomiske faktorer (50).

Vi ser her konturene av livsløp der helseproblemer og sosiale problemer er viklet i hverandre og akkumuleres over tid. På denne bakgrunn er det sannsynlig at mange allerede er belastet med problemer av både sosial og helsemessig art i det de startet sin karriere som sosialhjelpsmottakere. Problemer og risikofaktorer har en tendens til å akkumuleres blant dem som allerede har ett eller flere, både av materiell og livsstilsmessig art (14). I tillegg kommer en del trekk ved rollen som sosialhjelpsmottaker som forskning har vist er helseskadelig. Følelse av skam, lav selvfølelse, lite tillit, svak autonomi og kontroll over livet, utrygghet for framtida, svake sosiale nettverk, og opplevelse av knapphetens tyranni er beskrivelser som går igjen i litteraturen om sosialhjelpsmottakere $(8,12,20,36,46)$. Nyere helseforskning viser at kombinasjonen av psykososiale belastninger og stressfaktorer på den ene siden og mangelen på sosiale nettverk og støtte på den annen er særlig helseskadelig $(21,51)$.

Mye av dette er innebygd i rollen som sosialhjelpsmottaker og kjennetegner aspekter ved relasjonen mellom klienten og sosialkontoret. Langtidsmottakere er særlig utsatt: De er både mer problembelastet $i$ utgangspunktet og er mer eksponert for belastningen ved å være sosialhjelpsmottaker over lengre tid.

Våre funn er fra en bestemt historisk periode. Det kan tenkes at den sosiale sammensetningen av sosialhjelpsmottakerpopulasjonen i 1992 var en noe annen enn i dag. Den forholdsvis høye arbeidsledigheten som rammet Norge tidlig på 1990-tallet taler for det. Spørsmålet er derfor om funnene fremdeles er gyldige for å beskrive situasjonen til dagens sosialhjelpsmottakere i en tid med stor etterspørsel etter arbeidskraft. Det er grunn til å tro at vi i så fall står overfor en mer problembelastet gruppe i dag enn tidlig på 1990-tallet. De tidligere refererte studiene om rusmisbruk blant sosialhjelpsmottakere indikerer at det har vært en økning av personer med rusproblemer i gruppen. Sosialhjelpsmottakere har også hatt en langt svakere inntektsutvikling enn andre i perioden (52).

Resultatene av denne undersøkelsen påkaller behov for analyser av sosialhjelpsmottakere som i større grad anlegger et livsløpsperspektiv der sosiale problemer og helseproblemer tidlig i livsløpet belyses. Bare ved hjelp av slike tilnærminger vil det være mulig skille mellom faktorer som virker tidlig i livsløpet og hvilke faktorer som er knyttet til forhold i samtiden og til rollen som sosialhjelpsmottaker. Det er derfor også behov for mer kunnskap om hvorvidt det er sider ved sosialhjelpsordningen og sosialhjelpsrollen, noe vi har grunn til å tro, som faktisk er helseskadelig, eller som i det minste ikke er helsefremmende. Hvis vi har rett $i$ vår antakelse om at problematiske oppvekstforhold kan forklare mye av seinere helseproblemer, vil en politisk implikasjon være at forebyggende tiltak må settes inn tidlig for å forhindre problemer i å utvikle seg og medvirke til å redusere seinere behov for sosialhjelp, noe som også er i tråd med en nylig avlagt doktorgradsavhandling (53). I alle fall er det viktig å ta hensyn til den store forekomsten av dårlig helse blant sosialhjelpsmottakere i den pågående NAV-reformen og ved utforming av velferdskontrakter (54). Sosialpolitikk kan også ha betydning for helseulikheter, både ved å påvirke den sosiale posisjonen folk innehar, i hvilken grad personer i ulike sosiale posisjoner utsettes for helserisiko, og effekten av disse risikoene (55).

\section{KONKLUSJON}

Vi har funnet at sosialhjelpsmottakere, og særlig langtidsmottakere, har en dødelighet som er markant høyere enn blant folk flest i samme alder. Dette gjelder for både mannlige og kvinnelige mottakere. Mye av 
overdødeligheten kan tilskrives lav inntekt og utdanningsnivå, at sosialhjelpsmottakere oftere er enslige, og sambruk med uførepensjon. Den gjenstående sammenhengen mellom å motta sosialhjelp og dødelighet er likevel betydelig, med to til tre ganger så høy dødelighet for mannlige sosialhjelpsmottakere, og noe mindre forskjell for kvinner. Annen forskning gir grunnlag for å anta at dette dels skyldes problemer under oppveksten og dels problemer i samtiden som helseskadelig atferd og uheldige sider ved statusen som sosialhjelpsmottaker. For å forstå sosialhjelpsmottakeres dårlige helse og risiko for tidlig død må vi antakelig trekke inn akkumulasjon av risikofaktorer over livsløpet så vel som samtidens risikofaktorer og beskyttelsesfaktorer.

\section{TAKKSIGELSER}

Vi takker Sosial- og helsedirektoratet som har finansiert denne undersøkelsen og SSB som har koplet data om sosialhjelpsbruk fra Sosialhjelpsregisteret. De øvrige dataene er innhentet gjennom prosjektet Inntektsulikhet og dødelighet som er et samarbeid mellom Jon Ivar Elstad, NOVA, Dag Hofoss, HØKH, og Espen Dahl. Forfatterne står selv ansvarlige for de analyser, resultater og tolkninger som kommer fram i artikkelen.

\section{REFERANSER}

1. Sosial- og helsedirektoratet. Gradientutfordringen. Sosial- og helsedirektoratets handlingsplan mot sosiale ulikheter i helse. Oslo: Sosial- og helsedirektoratet, 2005.

2. Rognerud M, Strand BH, Hesselberg Ø. The health of Disadvantaged groups in Norway. Rapport 2002: 2. Oslo: Folkehelsa, 2002.

3. Kverndokk S. Sammenhengen mellom inntekt, inntektsulikhet og helse. Rapport 2006: 8. Oslo: HERO-UiO, 2006.

4. Zahl PH, Rognerud M, Strand BH, Tverdal A. Bedre helse - større forskjeller. En analyse avhvordan inntekt, utdanning og husholdningsstørrelse har påvirket dødeligheten i befolkningen i periodene 1970-77, 1980-87 og 1990-97. Rapport 2003: 1. Oslo: Nasjonalt folkehelseinstitutt, 2003.

5. Næss Ø, Rognerud M, Strand BH. Sosial ulikhet i helse. En faktarapport. Rapport 2007: 1 Oslo: Folkehelseinstituttet, 2007.

6. Kristofersen LB. Barnevernbarnas helse. Uførhet og dødelighet i perioden 1990-2002. Rapport 2005: 12. Oslo: NIBR, 2005.

7. Skardhamar T. Lovbruddskarrierer og levekår. En analyse av fødselskullet 1977. Rapport 2005: 9. SSB, OsloKongsvinger, 2005.

8. van der Wel K, Dahl E, Lødemel I, Løyland B, Ohrem Naper S, Slagsvold M. Funksjonsevne blant langtidsmottakere av sosialhjelp. Rapport 2006: 29. Oslo: HiO, 2006.

9. Brevik I. Sosialhjelpsklienters arbeid, helse og oppvekst. Oslo: NIBR, 1996.

10. BUF-dir. Utvikling av hjemmebaserte tiltak med statlig støtte. Arbeidskonferanse i Drammen 23. til 25. november 2005. Rapport 2006: 1. Barne-, ungdoms- og familiedirektoratet, 2006.

11. Seim S, Hjelmdal OK. Den som inte har..... Livskvalitet og levekår blant klienter med langvarig kontakt med sosialkontoret. Rapport 1992: 6. Oslo: NKSH, 1992.

12. Underlid K. Fattigdommens psykologi. Oslo: Samlaget, 2005.

13. Marthinsen E, Moe RB. Langtidsbrukere av sosialhjelp ved Byåsen sosialtjeneste i 1998. Rapport 1999: 8. Trondheim: BUS Midt-Norge, 1999.

14. Ringbäck-Witoft G. Social differences, vulnerability and ill-health. Scand J Public Health 2001; 29 (Suppl 58): 199-218.

15. Andrèn T, Gustafsson B. Patterns of social assistance receipt in Sweden. Int J Social Welfare 2004; 13: 55-68.

16. Dahl E, Lorentzen T. Dynamics of social assistance: the norwegian experience in comparative perspective. Int J Social Welfare 2003; 12: 289-301.

17. SSB. Sosialhjelpsstatistikk. http://www.ssb.no/emner/ 03/04/30/soshjelpk/.

18. Kirkeberg MI, Epland J, Andersen AS. Økonomi og levekår for ulike grupper, 2005. Rapport 2006: 3. SSB, Oslo-Kongsvinger, 2006.

19. Hatland A, West Pedersen A. Er sosialhjelpen et effektivt virkemiddel i fattigdomsbekjempelsen? Tidsskrift for Velferdsforskning 2006; 9: 58-72.

20. Borgeraas E. Knapphetens økonomi. Rapport 2006: 1. Oslo: SIFO, 2006.

21. Wilkinson RG. Unhealthy societies. New York: Routledge, 1996.

22. Yngwe MÅ, Lundberg O. Assessing the contribution of relative deprivation to invome differences in health. I: Fritzell J, Lundberg O, red. Health inequalities and welfare resources. Bristol: The Policy Press, 2007.

23. Stronks K, van de Mheen HD, Mackenbach JP. A higher prevalence of health problems in low income groups: does it reflect relative deprivation? J Epidemiol Community Health 1998; 52: 548-57. 
24. Sund E, Krokstad S. Sosiale ulikheter i helse i Norge: en kunnskapsoversikt. Oslo: Sosial- og helsedirektoratet, 2005.

25. Dahl G, Enes AW, Jørgensen T, Trewin C. Langtidsmottakere av økonomisk sosialhjelp. Rapport $2006: 13$. SSB, Oslo-Kongsvinger, 2006.

26. Oort FVAv, Lenthe FJv, Mackenbach JP. Material, psychosocial, and behavioural factors in the explanation of educational inequalities in mortality in the Netherlands. J Epidemiol Community Health 2005; 59: 214-20.

27. $\mathrm{Hu}$ Y, Goldman N. Mortality differentials by marital status: an international comparison. Demography 1990; 27: 233-50.

28. Kravdal Ø. The impact of marital status on cancer survival. Soc Sci Med 2001; 52: 357-68.

29. Murray JE. Marital protection and marital selection: evidence from a historical-prospective sample of American men. Demography 2000; 37: 511-21.

30. Rognerud MA, Zahl P-H. Social inequalities in mortality: changes in the relative importance of income, education and household size over a 27-year period. Eur J Public Health 2006; 16: 62-8.

31. Zahl P-H, Rognerud M, Strand BH. Sosial ulikhet og utvikling i dødelighet hos enslige i Norge. Tidsskr Nor Loegeforen 2003; 123: 1822-5.

32. Hanssen JI, Terum LI. Samfunnsendring og sosialhjelpsvekst. Rapport 1992: 7. Oslo: INAS, 1992.

33. Wallman T, Wedel H, Johansson S, Rosengren A, Eriksson H, Welin L, et al. The prognosis for individuals on disability retirement. An 18-year mortality follow-up study of 6887 men and women sampled from the general population. BMC Public Health 2006; 6: 103.

34. Gjesdal S, Mæland JG, Hagberg J, Alexanderson K. Socioeconomic inequalities and mortality among disability pensioners in Norway - a population-based cohort study. Norsk Epidemiologi 2007; 17: 29-35.

35. SSB. Økonomi og levekår for ulike grupper, 2006. Rapport 2007: 8. SSB, Oslo-Kongsvinger, 2007.

36. Solheim LJ. Sosialhjelp og vern av sjølvrespekten. I: Halvorsen K, red. Mestring av marginalitet. Oslo: Cappelen Akademisk Forlag, 1996.

37. Dahl E, Lorentzen T. Explaining exit to work among social assistance recipients in Norway: heterogenity or dependency? Eur Sociol Rev 2003; 19: 519-36.

38. Akselsen A, Lien S, Siverstøl Ø. FD-trygd. Variabelliste. Notat. SSB, Oslo-Kongsvinger, 2007.

39. Cleves M, Gould WW, Gutirrez RG. An introduction to Survival Analysis using Stata: Stata Press, 2002.

40. Geyer S, Hemstrom O, Peter R, Vagero D. Education, income, and occupational class cannot be used interchangeably in social epidemiology. Empirical evidence against a common practice. J Epidemiol Community Health 2006; 60: 804-10.

41. Mastekaasa A. The relationship between marital status and subjective well-being: consistency, variations, and causal explanations [Doktoravhandling]. University of Oslo, 1993.

42. Mørk E. Aleneboendes levekår. Rapport 2006: 81. SSB, Oslo-Kongsvinger: SSB Statistiske analyser, 2006.

43. Schou MB. Hva betyr selvopplevd helse for dødelighet? Belyst med data fra HUNT1 [Hovedoppgave]. NTNU, 2005.

44. Wadsworth M, Butterworth S. Early life. I: Marmot M, Wilkinson RG, red. Social Determinants of Health. Oxford: Oxford University Press, 2006.

45. Elstad JI. Childhood adversities and health variations among middle-aged men: a retrospective lifecourse study. Eur J Public Health 2005; 15: 51-8.

46. Hyggen C. Risks and resources: Social capital among social assistance recipients in Norway. Soc Policy Admin 2006; 40: 493-508.

47. Hansen MN, Vibe Ud. Behov for Sosialhjelp og uføretrygd: Individuell ulykke eller sosial arv? Søkelys på arbeidslivet 2005; 22 (2).

48. Gundersen T, m.fl. Rusklienter og tjenester før "rusreformen". En tverrsnittsundersøkelse. Oslo: SINTEF Helse, 2004: STF78 A044513.

49. Clausen SE. A classification of social assistance recipients in Norway. Scand J Soc Welfare 1996; 5: 208-14.

50. Mykletun A. Mortality and work-related disability as long-term consequences of anxiety and depression: historical cohort designs based on the HUNT-2 study [Doctoral thesis]. University of Bergen, 2006.

51. Marmot M. The Status Syndrom. London: Bloomsbury Publishing, 2005.

52. SSB. Svak inntektsutvikling for sosialhjelpsmottakere. http://www.ssb.no/emner/05/01/inntind/.

53. Helgeland IM. Unge med alvorlige atferdsvansker blir voksne [Doktoravhandling]. Universitetet i Oslo, 2007.

54. St.meld. nr. 9 (2006-2007). Arbeid, velferd og inkludering. Arbeids- og inkluderingsdepartementet.

55. Whitehead M, Burstrom B, Diderichsen F. Social policies and the pathways to inequalities in health: a comparative analysis of lone mothers in Britain and Sweden. Soc Sci Med 2000; 50: 255-70. 